\title{
The nitrate time bomb - a numerical way to investigate nitrate storage and lag time in the unsaturated zone
}

\author{
L. Wang · A. S. Butcher · M. E. Stuart · D. C. Gooddy · J. P. Bloomfield \\ L. Wang (corresponding author) \\ British Geological Survey, Keyworth, Nottingham, NG12 5GG \\ e-mail: lei.wang@bgs.ac.uk
}

A. S. Butcher · M. E. Stuart · D. C. Gooddy · J. P. Bloomfield
British Geological Survey, Wallingford, Oxfordshire, OX10 8BB

Abstract

Nitrate pollution in groundwater, which is mainly from agricultural activities, remains an international problem. It threatens environment, economics and human health. There is a rising trend in nitrate concentrations in many UK groundwater bodies. Research has shown it can take decades for leached nitrate from the soil to discharge into groundwater and surface water due to the 'store' of nitrate and its potentially long time travel time in the unsaturated and saturated zones. However, this time lag is rarely considered in current water nitrate management and policy development. The aim of this study was to develop a catchment-scale integrated numerical method to investigate the nitrate lag time in the groundwater system, and the Eden Valley, UK was selected as a case study area. The method involves three models, namely, the nitrate time bomb - a process-based model to simulate the nitrate transport in the unsaturated zone (USZ), GISGroundwater - a GIS groundwater flow model, and N-FM - a model to simulate the nitrate transport in the saturated zone. This study answers the scientific questions of when the nitrate currently in the groundwater was loaded into the unsaturated zones and eventually reached the water table; is the rising groundwater nitrate concentration in the study area caused by historic nitrate load; what caused the uneven distribution of groundwater nitrate concentration in the study area; and whether the historic peak nitrate loading has reached the water table in the area. The groundwater nitrate in the area was mainly from 1980s -2000 s, whilst the groundwater nitrate in the most of the Source Protection Zones leached into the system during 1940s - 1970s; large and spatially variable thickness of the USZ is one of the major reasons for unevenly distributed groundwater nitrate concentrations in the study area; the peak nitrate loading around 1983 has affected most of the study area. For areas around the Bowscar, Beacon Edge, Low Plains, Nord Vue, Dale Springs, Gamblesby, Bankwood Springs, and Cliburn, the peak nitrate loading will arrive at the water table in the next 34 years; statistical analysis shows that $8.7 \%$ of the Penrith Sandstone and $7.3 \%$ of the St Bees Sandstone have not been affected by peak nitrate.

This research can improve the scientific understanding of nitrate processes in the groundwater system, and support the effective management of groundwater nitrate pollution for the study area. With limited number of parameters, the method and models developed in this study are readily-transferable to other areas.

\section{Keywords}

Nitrate water pollution . Nitrate transport . Time lag. The unsaturated zone - Nitrate time bomb $\cdot$ Integrated modelling

\section{Introduction}

Freshwater is essential for supporting our life and sustaining livelihoods. Nitrate (NO3) is essential for living matter by acting as a source of nitrogen $(\mathrm{N})$ that forms the building blocks of molecules. 
However, too much nitrate in water bodies can cause the nitrate water pollution that has been regarded as a remaining problem in many developing and developed countries (Campbell et al., 2004; European Environment Agency, 2000; Rivett et al., 2007). It is not only an environmental issue but also an economic and human health problem (DEFRA, 2002). For example, high concentrations of nitrate in freshwater can cause eutrophication in rivers, lakes and estuaries by igniting huge algae and phytoplankton blooms, and depleting oxygen in water. In Mississippi such blooms are now leading to so-called 'dead zones', where the death of the algae means all the oxygen in the water is used up, killing fish and other aquatic life. Meanwhile, the nitrogen bio-geochemical cycle can produce large amounts of the greenhouse gas 'nitrous oxide'. The costs for UK water industry on nitrate treatment rose from $£ 16$ million per year in 2000 to $£ 58$ million per year in 2005

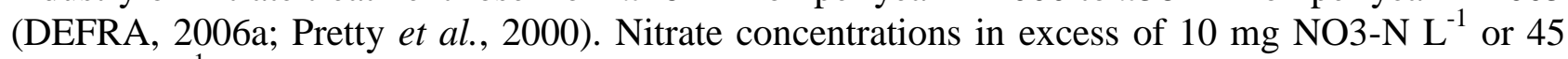
mg NO3 $\mathrm{L}^{-1}$ in drinking water may reduce the ability of human blood to carry oxygen and, in the very young, cause 'blue baby syndrome' (Bryan, 2006); and a potential cancer risk from nitrate in drinking water has been reported (Yang et al., 2007).

Compared with surface water, groundwater is a more reliable water resource, particularly in dry regions or seasons, with a higher contamination resistance. Groundwater provides one third of public water supply in England and Wales, increasing to up to $80 \%$ in Southern England. Nitrate groundwater contamination arises mainly from diffuse agricultural sources (Foster, 2000). During the last century, the pools and fluxes of $\mathrm{N}$ in UK ecosystems have been transformed mainly by the fertilizer-based intensification of agriculture (Burt et al., 2011). We have benefit from using $\mathrm{N}$ fertilizer in feeding our increasing population, and agricultural yields may be promoted by the shorter time-scale addition of $\mathrm{N}$ in fertilizers, leading to fast $\mathrm{N}$ leaching into freshwaters. The leached $\mathrm{N}$, however, could cause long-term water pollution and ecosystem damage. For example, China had to gradually increase the $\mathrm{N}$ fertilizer application rate from $38 \mathrm{~kg} \mathrm{~N}^{-1}$ in 1975 to $262 \mathrm{~kg}$ $\mathrm{N} \mathrm{ha}^{-1}$ in 2001 to feed its huge population, and has become the biggest consumer of the $\mathrm{N}$ fertilizer in the world, thus causing the significant degradation of many Chinese major lakes including its five largest freshwater lakes (Kahrl et al., 2010). In England, over 70\% of nitrate in freshwaters has been shown to be derived from agricultural land (DEFRA, 2006b);

Although legislative means were introduced, the nitrate water pollution remains an unsolved problem. For example, despite efforts under the EU Water Framework Directive (Directive 2000/60/EC) by 2015 to improve water quality, it is still seen a continuous decline in freshwater quality due to nitrate in the UK. Nitrate concentrations are more than $50 \mathrm{mg} \mathrm{NO}^{-1} \mathrm{EU}$ drinking water standard with a rising trend in many aquifers (Stuart et al., 2007). It is estimated that about $60 \%$ of all groundwater bodies in England will fail to achieve good status by 2015 (DEFRA, 2006b; Rivett et al., 2007).

Recent research suggests that it could take decades for leached nitrate to discharge into freshwaters due to nitrate storage and long time lag in the unsaturated zone (USZ) and saturated zone (Burt et al., 2011; Howden et al., 2011; Jackson et al., 2007; Wang et al., 2012). This may cause a long time lag between the loading of nitrate from soil and the change of nitrate concentrations in groundwater. In reality, current environmental management strategies rarely consider the nitrate time lag, but rely instead on the predictions of a relatively rapid response of water quality to land management practices (Burt et al., 2011), thus leading to inappropriate controls and conflicts between policy makers, environmentalists and industry. Therefore, there is an urgent need to incorporate the nitrate time lag in the groundwater system into water resource management decision-making processes because of environmental and legislative pressures.

The transport and storage of nitrate in the unsaturated zone has been studied from the late 1970s onwards (Brouyère et al., 2004; Foster and Crease, 1974; Geake and Foster, 1989; Hoffmann et al., 2000; Lawrence and Foster, 1986; Ledoux et al., 2007; Oakes et al., 1981; Spears, 1979; Young et 
al., 1976), and some numerical modelling work was carried out to map the spatial extent of nitrate contamination of groundwater (Rivett et al., 2007), and to assess the vulnerability or risk of groundwater nitrate pollution (e.g. Foster, 1993; Lake et al., 2003; Palmer, 1987; Wang and Yang, 2008; Yang and Wang, 2010). Most recently, a national scale nitrate time bomb model was developed to simulate the nitrate transport in the unsaturated zone and predict the loading of nitrate at the water table for the UK (Wang et al., 2012). Nevertheless, the local nitrate groundwater contamination management needs more detailed information, thus requiring a method to apply this model in the catchment scale study.

The aim of this study was to develop an integrated modelling method to investigate the nitrate lag time in the groundwater system by simulating the nitrate transport in USZs and the saturated zones at the catchment scale. Three numerical models, i.e., the nitrate time bomb model, GISGroundwater and the nitrate transport model in the saturated zone N-FM, were integrated to verify and support each other to provide information on nitrate lag time in the groundwater system at a catchment scale. The UK Eden Valley, which has thick Permo-Triassic sandstone unsaturated zones and a nitrate groundwater pollution problem, was selected as a case study area. It is demonstrated that the method developed in this study can answer the scientific questions related to the nitrate time lag in the groundwater system, and provide scientific evidence for sustainable groundwater nitrate pollution management in the area.

\section{Methodologies and materials}

\section{The Eden Valley}

The Eden Valley, located in Cumbria in the north-west of England, lies between two upland areas, the Pennines to the east and the English Lake District to the west. It receives an average annual rainfall of about $1000 \mathrm{~mm}_{\text {year }}^{-1}$. The River Eden, the main river in the study area, runs from its headwaters in the Pennines to the Solway Firth in the north-west, having three main tributaries, the River Eamont, the River Irthing and the River Calder. The study area is aligned northwest-southeast and is $56 \mathrm{~km}$ long and $4.5-14 \mathrm{~km}$ wide (Fig. 1). Agriculture, tourism and some industry are the major economic activities in the region; it is largely rural and the population density is relatively low at approximately 0.2 persons $\mathrm{ha}^{-1}$; the area is mainly covered by managed grassland, arable land and semi-natural vegetation with small proportions of woodland, and urban land-use (Daily et al., 2006). In recent years the application of slurry to the grazed grasslands has been increased due to more intensive farming activities (Butcher et al, 2003).

In the study area, the Permian Penrith Sandstone (up to 900 m thick), dips gently eastwards and is principally red-brown to brick red in colour with well-rounded, well-sorted and medium to coarse grains. It is overlain by the Eden Shale Formation (up to $180 \mathrm{~m}$ thick), which is generally red in colour with brown, green and grey beds in places, and consists of mudstone, siltstone, sandstone, breccia and conglomerate. This is overlain by the St Bees Sandstone (up to $350 \mathrm{~m}$ thick), which consists of red-brown and grey, fine-grained, cross-bedded sandstone (Allen et al, 1997). Fig. 1 shows the bedrock geology of the study area. Many geological and hydrogeological studies in the area have been carried out (e.g. Allen et al., 1997; Arthurton, et al., 1978; Arthurton and Wadge, 1981; Millward and McCormac, 2003; Patrick, 1978). Borehole hydrographs from the Penrith Sandstone aquifer in the area show a small annual fluctuation in groundwater levels (GWLs), typically less than $1 \mathrm{~m}$, indicating the groundwater flow type in the aquifer is intergranular with high storage (ESI 2004). Some hydrographs from the same aquifer also show very long-term water level fluctuations (with about 10 years between the peaks and troughs) apparently as a result of long-term changes in recharge (Butcher et al, 2003). Groundwater flow in the study area is dominated by flow to the River Eden. The hydraulic gradients in the Penrith Sandstone aquifer are generally gentle and predictable, whilst the ones in the St Bees Sandstone aquifer are generally 
141 steeper, reflecting the aquifer's generally lower permeability (Butcher et al, 2003; Daily et al., 2006).

142 The Penrith Sandstone and St Bees Sandstone form the major aquifers in the region. The hydraulic 143 conductivity $(\mathrm{K})$ values in the aquifers range from $3.5 \times 10^{-5}-26.2 \mathrm{~m} \mathrm{day}^{-1}$ and $0.048-3.5 \mathrm{~m} \mathrm{day}^{-1}$ 144 respectively (Allen et al, 1997). GWLs are close to the surface in the vicinity of the River Eden, but 145 they are as much as $100 \mathrm{~m}$ below ground in the north-west part of the study area. According to 146 Daily et al. (2006), there may be some groundwater flow between adjacent and underlying 147 Carboniferous rocks in the area, however, the numerous springs, which arise along the faulted 148 contact, suggest that much of the groundwater is transferred to surface flow. 


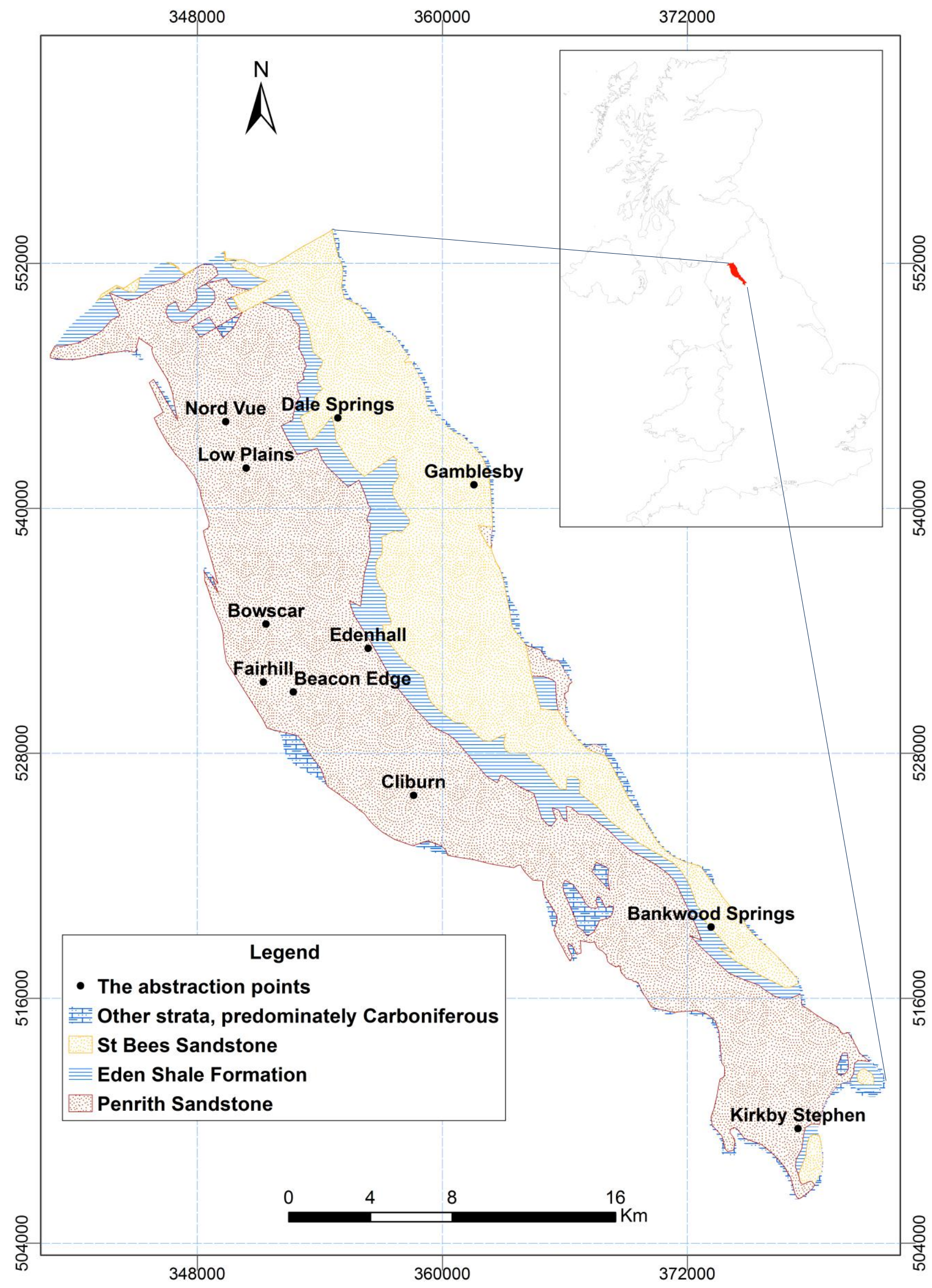

Fig. 1 The location and the bedrock geological map for the Eden Valley, UK. 
Parts of the Eden Valley catchment, located in north Cumbria, UK, have groundwater nitrate pollution problems. The Environment Agency's groundwater monitoring data show that abstracted groundwater in this area has a range of nitrate concentrations; some groundwater exceeds the limit of $50 \mathrm{mg} \mathrm{NO}_{3} \mathrm{l}^{-1}$ and exhibit a rising trend with time (Butcher et al., 2003; Butcher et al, 2005). In order to make sound decisions for groundwater quality management in the area, it is necessary to answer the scientific questions of when was the nitrate currently in the groundwater loaded into the unsaturated zones; what is the time the historic peak nitrate loading eventually reached or will reach the water table; is the rising groundwater nitrate concentration in the study area caused by historic nitrate load; what caused the uneven distribution of groundwater nitrate concentration in the study area.

\section{The nitrate time bomb model}

The nitrate time bomb, a simple process-based GIS model for simulating the nitrate transport in the unsaturated zones, has been applied in predicting the arriving time for peak nitrate loading at the water table of the UK (Wang et al., 2012). It links a nitrate input function (the temporally varying but spatially uniform leaching of nitrate from the base of the soil), unsaturated zone thickness, and lithologically dependent rate of nitrate USZ transport to estimate the arrival time of nitrate at the water table. The assumptions of this model include: nitrate loading is from the base of the soil; nitrate moves vertically from the land surface to the water table; nitrate movement is through the matrix only in dual-porosity strata; nitrate moves at a constant velocity through the USZ; there is no hydrodynamic dispersion of nitrate in the USZ; and the mass of nitrate in the USZ is preserved. Even if at the local-scale there is some lateral movement, movement of water (and hence nitrate) through the unsaturated zone is predominantly vertical, especially in these unsaturated zones with more than 100m thicknesses; the assumption of vertical movement simplifies the nitrate transport in the unsaturated zone and makes the model to be applied easily in an area with limited datasets. The assumption of a constant velocity implicitly requires an assumption that for each cell in the GIS the unsaturated zone has homogeneous hydrodynamic characteristics, i.e. the velocities used in the model are effective velocities at the resolution of the model associated with a given hydrolithological unit. Hydrodynamic dispersion of nitrate in the unsaturated zone, due to both mechanical dispersion and diffusion, will occur. Both these processes will act to retard or attenuate the nitrate loading so by assuming no hydrodynamic dispersion the predicted arrival times will be the most conservative estimate of the earliest arrival times of nitrate at the water table. Any hydrodynamic dispersion will cause arrival times including peak arrival times at the water table to be delayed beyond those predicted by the model. Although denitrification is the dominant nitrate attenuation process in the subsurface (Rivett et al., 2007), Kinniburgh et al., (1994) regarded this as insignificant beneath the soil zone in the USZ of UK aquifers, and Butcher et al (2005) found no evidence of denitrification in sampled groundwater in the den Valley. The model is written in $\mathrm{C}++$ and has an open structure to be integrated with other numerical models.

\section{The nitrate input function}

The nitrate input function derived from literature review (Wang et al., 2012) shows an excellent agreement with mean porewater nitrate concentrations from 300 cored boreholes across the UK in the BGS database (Fig. 2). It was selected in this study assuming a single arable land-use is covering the study area. The sudden increase of porewater nitrate concentrations between 1990 and 2000 was due to the artefact of both the focus of recent studies on areas with a nitrate problem and relatively less recent data points. In this nitrate input function, a low and constant value $(25 \mathrm{~kg} \mathrm{~N}$ $\mathrm{ha}^{-1}$ year $^{-1}$ ) between 1925 to 1940 reflects the pre-war low level of industrialisation with very limited use of non-manure-based fertilizers (Addiscott, 2005); from 1940 to 1955, there was a $1 \mathrm{~kg}$ $\mathrm{N} \mathrm{ha}^{-1}$ year ${ }^{-1}$ rise in nitrogen input to $40 \mathrm{~kg} \mathrm{~N} \mathrm{ha}^{-1}$ in 1955 . This was the result of the gradual 
intensification of agriculture during and just after World War II (Foster et al., 1982); a more rapid rise of $1.5 \mathrm{~kg} \mathrm{~N} \mathrm{ha}^{-1}$ year $^{-1}$ from $40 \mathrm{~kg} \mathrm{~N} \mathrm{ha}^{-1}$ in 1955 to $70 \mathrm{~kg} \mathrm{~N} \mathrm{ha}^{-1}$ (a peak value between 1975 and 1990) in 1975 was due to increases in the use of chemical based fertilizers to meet the food needs of an expanding population (Addiscott et al., 1991); the nitrogen input declines with a rate of $1 \mathrm{~kg} \mathrm{~N} \mathrm{ha}^{-1}$ year $^{-1}$ from 1991 to 2020 (from $70 \mathrm{~kg} \mathrm{~N} \mathrm{ha}^{-1}$ in 1991 to $40 \mathrm{~kg} \mathrm{~N} \mathrm{ha}^{-1}$ ) as a result of restrictions on fertilizer application in water resource management (Lord et al., 1999); finally, there is a constant $40 \mathrm{~kg} \mathrm{~N} \mathrm{ha}^{-1}$ nitrogen application from 2020 to 2050, assuming a return to nitrogen input levels similar to those associated with early intensified farming in the mid-1950s.

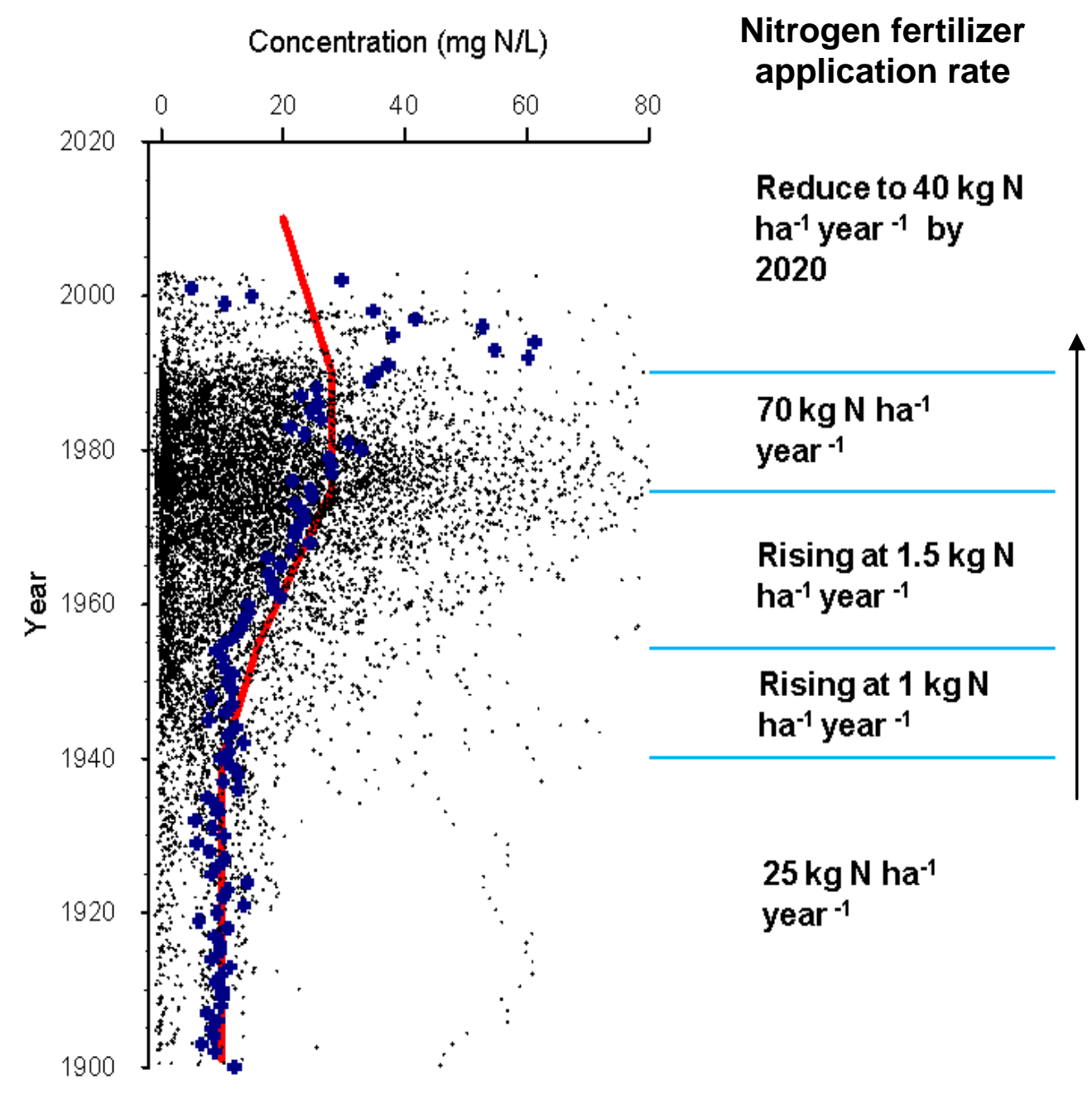

Fig. 2 Nitrate input function. Red solid line shows nitrate input spans derived from literature data. Black dots show individual porewater nitrate concentrations from 300 cored boreholes in the BGS database that have been back-plotted to give nitrate concentrations at the base of the soil zone at their year of recharge calculated using depth in the profile and estimated USZ travel time. Blue crosses show average nitrate concentration for a given year calculated from the porewater data. The nitrogen application rate on the right reflects the historic different levels of industrialisation and the introduction of measures to reduce the fertilizer application rate (Adapted from Wang et al. (2012))

\section{GISGroundwater flow model}

The thickness of the Permo-Triassic sandstone USZs in the Eden Valley is needed in this study. The USZ thicknesses used in the study of Wang et al. (2012), which were derived mainly from the contours on published hydrogeological maps (generally at 1:100,000 scale) and have a spatial resolution of $1 \mathrm{~km}$ by $1 \mathrm{~km}$, are too coarse for a catchment scale study. Therefore, a simple and easy-to-use groundwater flow model is needed to simulate the long-term average steady-state 
GWLs for the area to derive high spatial resolution of the thicknesses of the Permo-Triassic sandstone USZs.

GISGroundwater - a seamless GIS 2-dimensional numerical finite difference groundwater flow model (Wang et al., 2010) was used in this study. The 2-dimensional steady state groundwater flow can be expressed by a partial differential equation:

$$
\frac{d^{2} h}{d x^{2}}+\frac{d^{2} h}{d y^{2}}=\frac{Q^{A}+Q_{z}-R \Delta x \Delta y}{K b \Delta x \Delta y}
$$

where $h$ is the GWL $(\mathrm{L}) ; R$ is the groundwater recharge $\left(\mathrm{L} \mathrm{T}^{-1}\right) ; Q^{A}$ is groundwater abstraction rate $\left(\mathrm{L}^{3} \mathrm{~T}^{-1}\right) ; K$ is the hydraulic conductivity $\left(\mathrm{L} \mathrm{T}^{-1}\right)$ of the aquifer; $Q_{\mathrm{z}}$ is the baseflow rate $\left(\mathrm{L}^{3} \mathrm{~T}^{-1}\right) ; \Delta x$ is the modelling cell size in the $\mathrm{x}$ direction; $\Delta y$ is the modelling cell size in the y direction.

The GIS layers can be used directly in GISGroundwater to identify the modelling boundary and node types, to simplify the process of constructing a groundwater model. The centre of a GIS grid with a value is treated as a GISGroundwater model node, and some of these nodes calculated from GIS grids could be invalid for the finite-difference calculation in GISGroundwater. Therefore, a boundary normalisation process was developed in GISGroundwater to make sure that all GIS grids are valid for implementing the groundwater flow finite-difference equations. But removing invalid nodes might create new ones, so an iterative process (Fig. 3) was introduced to fulfil this task. This means there is no need for users to make efforts to guarantee that a spatial complex shape of modelling extent are valid for building up a groundwater flow model.

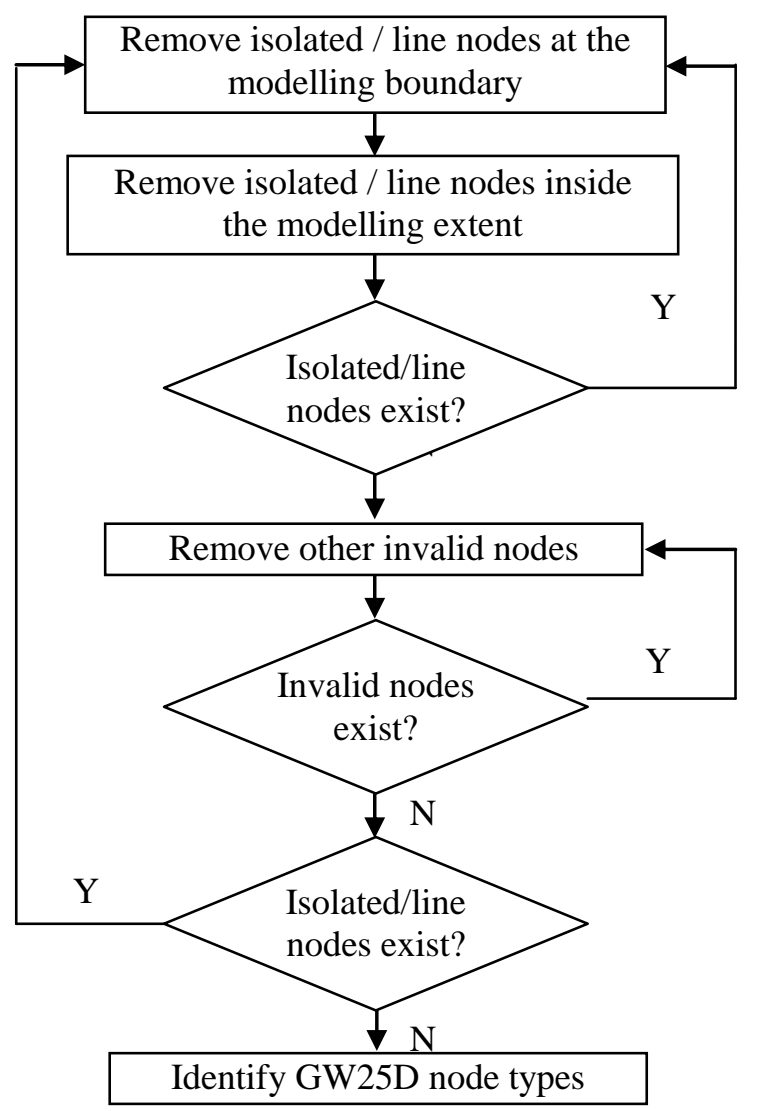

Fig. 3 Flow chart for indentifying the model boundary in GISGroundwater using a GIS layer

GISGroundwater can be easily and efficiently applied to simulate groundwater flow by directly 
single layer aquifer with a distribution of hydraulic conductivity values. The modelling extent is defined by a $(100 \mathrm{~m}$ by $100 \mathrm{~m})$ GIS layer. A GIS layer containing the distributed $\mathrm{K}$ values was entered into the model; river nodes and river stages entered were derived from a Centre for Ecology and Hydrology $(\mathrm{CEH})$ river system dataset and a DEM (digital elevation model, 50m by 50m) dataset from $\mathrm{CEH}$; groundwater abstraction data were also entered into the model using a GIS layer.

\section{9}

250

251

252

253

254

255

256

257

258

259

260

261

262

263

264

265

266

267

268

\section{Modelling nitrate dilution in the saturated zone}

N-FM - a GIS nitrate transport model for the saturated zone was developed to simulate yearly nitrate concentration at a borehole by considering the process of nitrate leaching from the bottom of soil zone, the nitrate movement in the USZ and dilution in the saturated zone. The simulated pumped nitrate concentration in boreholes were compared with observed ones to validate the numerical modelling parameters, such as the nitrate transport velocity in the USZ, the thickness of the USZ, and the aquifer hydraulic conductivity values used for deriving the thickness of the USZ, which will be used to investigate the nitrate lag time in the groundwater system of the study area.

Fig. 4 shows the conceptual model of N-FM. The dilution process was simplified by assuming that nitrate arriving at a borehole dilutes in water pumped out of the borehole, and the groundwater flow within a groundwater Source Protection Zone (SPZ) (a groundwater catchment for a pumping borehole), reaches a steady-state, i.e., the long-term recharge volume within a SPZ equals to water pumped out of the borehole in the SPZ. Not all leached nitrate reaches the abstraction borehole due to the attenuation processes in USZs and the saturated zones. Nitrate concentration may be reduced due to denitrification and absorption in USZs; nitrate in the saturated zones will be absorbed by small porous or transports outside of SPZ due to the diffusion and dispersion processes. Therefore a nitrate attenuation coefficient $(N A C)$ was introduced into this model. With this conceptual model, the depth of the saturated zone, the thickness of active groundwater zone can be ignored, and the nitrate dispersion and diffusion processes can be simplified in simulating yearly nitrate concentration at a borehole in the SPZ.

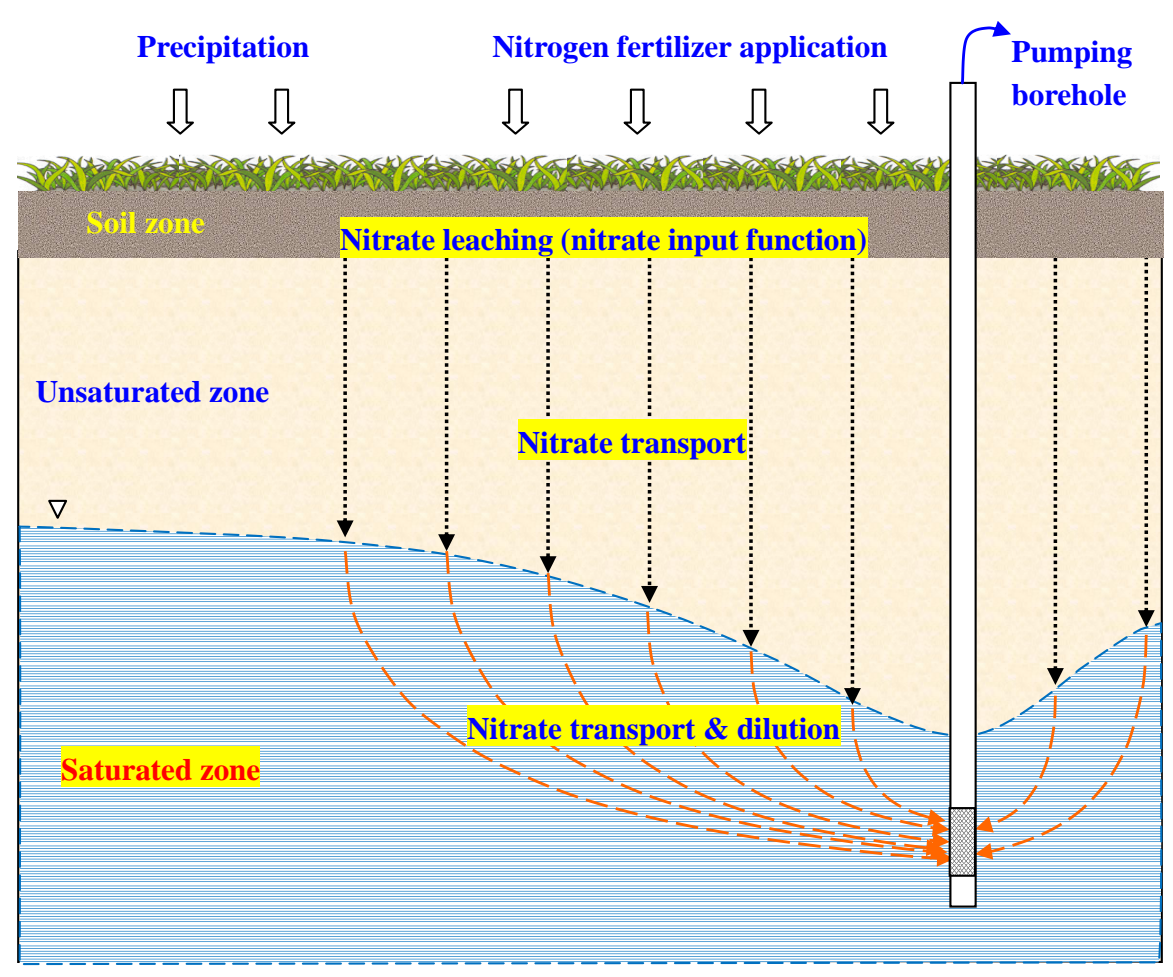

Fig.4 The sketch map of the conceptual model for the N-FM model.

The nitrate travel time form the loading point to a borehole is calculated using equations: 


$$
\begin{aligned}
& T T T_{i, j}=U T T_{i, j}+S T T_{i, j} \\
& S T T_{i, j}=\frac{D i s t_{i, j}}{V S_{i, j}} \\
& V S_{i, j}=\frac{K \times G_{i, j}}{\Phi}
\end{aligned}
$$

where $T_{T T}$ (years) is the total nitrate travel time from the ground surface at the modelling cell $(\mathrm{i}, \mathrm{j}$ ) to a borehole; $U T T_{i, j}$ (years) is the nitrate travel time from the loading point at the bottom of soil zone to the water table at the modelling cell $\left(\mathrm{i}, \mathrm{j}\right.$ ) in the USZ; $S T T_{i, j}$ (years) is the nitrate travel time from the water table at the modelling cell $(i, j)$ to a borehole within the saturated zone; Dist (m) is a 3D distance between the water table at the modelling cell $(i, j)$ and the screen level of a borehole; $\mathrm{V} S_{i, j}$ is the velocity of nitrate transport in saturated zone; $K\left(\mathrm{~m} \mathrm{day}^{-1}\right)$ is the hydraulic conductivity for the saturated media in a SPZ; Gi,j is the average hydraulic gradient between the water table at the modelling cell $(\mathrm{i}, \mathrm{j})$ and the screen level of the borehole; and $\Phi$ is the porosity of aquifer media in the SPZ.

The amount of nitrate reaching at a borehole in a year $N$ from a cell $(\mathrm{i}, \mathrm{j})$ is the nitrate loading in the year ( $N$ minus $T T T_{i, j}$ ) in the cell (determined by nitrate input function); and the total amount of nitrate reaching at the borehole in the year $N\left(T T N_{N}: m g \mathrm{NO}_{3}\right)$ is the sum amount of nitrate for all the modelling cells from different loading years within the SPZ. The actual total nitrate arriving at the borehole $\left(A T T N_{N}: \mathrm{mg} \mathrm{NO}_{3}\right)$ can be calculated using Equation 5.

$$
A T T N_{N}=T T N_{N} \times(1-N A C)
$$

Hence, an average nitrate concentration in year $N$ can be calculated from:

$$
\begin{aligned}
& \text { Ncon }_{N}=\frac{\text { ATTN }_{N}}{\text { Vol }} \\
& \text { Vol }=\text { PumpRate } \times 365
\end{aligned}
$$

where $\operatorname{Ncon}_{N}\left(\mathrm{mg} \mathrm{NO}_{3} \mathrm{l}^{-1}\right)$ is the average nitrate concentration in the water pumped out of a borehole in the year $N$; $\mathrm{Vol}$ (litre) is the volume of water pumped out from the borehole in a year; and PumpRate $\left(\mathrm{lday}^{-1}\right)$ is the groundwater pumping rate of the borehole.

\section{Results}

The average groundwater recharge of $1 \mathrm{~mm} \mathrm{day}^{-1}$ in the UK was used in the groundwater flow modelling using GISGroundwater for the Permo-Triassic sandstone in the Eden Valley. The groundwater flow model was calibrated by comparing the simulated long-term average GWLs with observed ones in 39 boreholes. Fig. 5 shows that the modelled and observed GWLs are in line indicating that the steady-state groundwater flow model for the study area was well calibrated. The $\mathrm{K}$ values for modelling the groundwater flow in Penrith Sandstone and St Bees Sandstone are $3.5 \mathrm{~m}$ day $^{-1}$ and $0.6 \mathrm{~m} \mathrm{day}^{-1}$ respectively. The distributed Permo-Triassic sandstone USZ thickness map for the area was then derived by subtracting the modelled long-term average GWLs from the DEM dataset.

The calculated USZ thickness, GWLs, and the K values for the Permo-Triassic sandstone from the 
calibrated groundwater flow model were used in modelling nitrate dilution in saturated zone in the SPZ of Bowscar to the northwest of the study area (Fig. 1). It is understood that nitrate is travelling with a velocity of around $3 \mathrm{~m}$ year $^{-1}$ in the Permo-Triassic sandstone USZs from previous study in the area (Butcher et al 2008); a 400-day zone in Bowscar SPZ was used to simulate the yearly nitrate concentration in its borehole (with a pumping rate of $1.5 \mathrm{Ml} \mathrm{day}^{-1}$ and a screen level of about $117 \mathrm{~m} \mathrm{AOD}$ ); the nitrate input function in Fig. 2 was used in the simulation; the calibrated value for the nitrate attenuation coefficient is 0.2 (20\% nitrate is attenuated in the groundwater system). The model was calibrated by comparing the simulated with observed yearly nitrate concentrations in the Bowscar borehole. The modelled result can reflect the trend of nitrate concentration in the borehole (Fig. 6). This implies that the understanding of the nitrate travel velocity in the Permo-Triassic sandstone USZs is correct; the thickness of USZs derived from groundwater flow modelling is reliable; and the nitrate input function can be used for this study area. Based on these validated parameters and datasets, the detailed nitrate lag time the Permo-Triassic sandstone USZs in the Eden Valley was simulated using the nitrate time bomb model.

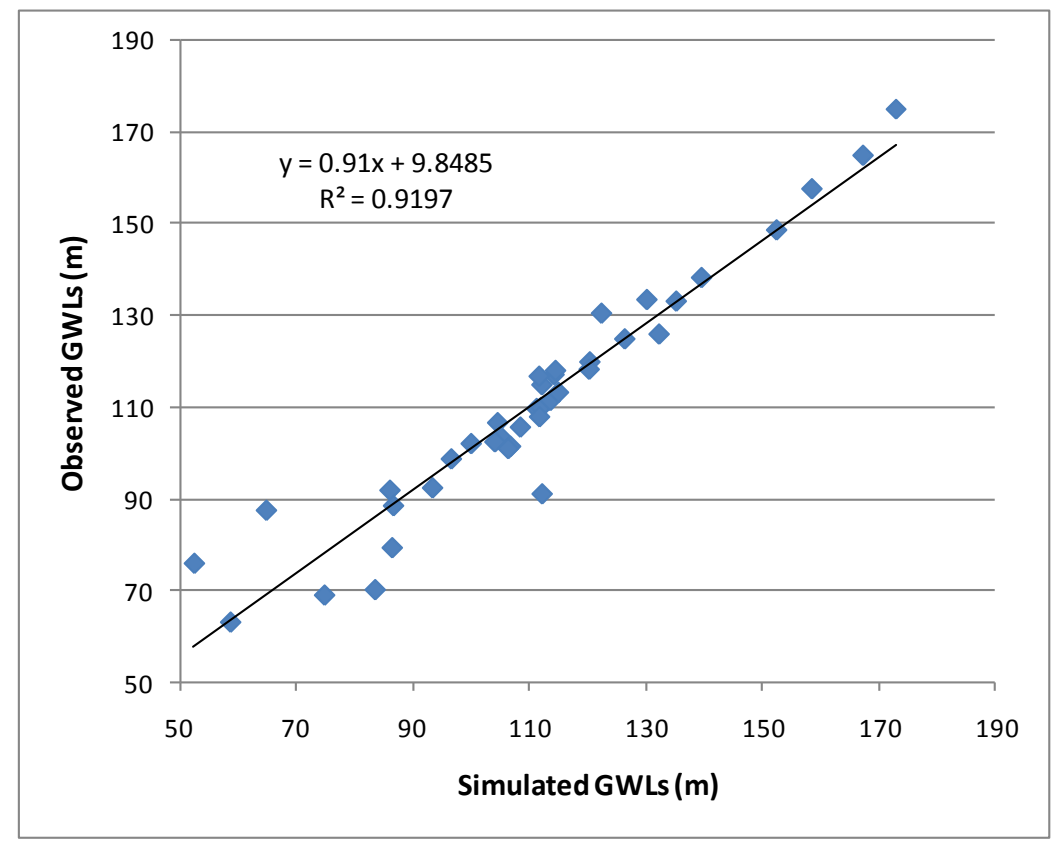

Fig. 5 Correlations between observed and modelled long-term steady-state groundwater levels (GWLs).

In the study area, the modelled thickness of the Permo-Triassic sandstone USZs is greatest, $183 \mathrm{~m}$ in the northwest of the Eden Valley, and reduces to $0 \mathrm{~m}$ (i.e. GWLs are the same elevation as the river stages) along the River Eden and its tributaries. SPZs generally have a thicker USZ than other parts of the study area.

The nitrate travel time in the Permo-Triassic sandstone USZs correlating with the USZ thickness, ranges from 0 to 61 years with a mean value of 12 years; strip areas along streams have short travel times (0-1 year) due to thin USZs, whilst mountainous areas in the east and west of the Eden Valley have longer nitrate travel times.

The nitrate arriving at the water table and entering the saturated zone in the area in 2010 was loaded into the USZs from the bottom of the soil layer during 1940s - 2000s (Fig. 7). The groundwater nitrate in the area was mainly from 1980s - 2000s, whilst the groundwater nitrate in the most of SPZs leached into the system during 1940s - 1970s. The peak nitrate loading around 1983 has affected most of the study area. For areas around the SPZs of Bowscar, Beacon Edge, Low Plains, Nord Vue, Dale Springs, Gamblesby, Bankwood Springs, and Cliburn, the peak nitrate loading will arrive at the water table in the next 34 years (Fig. 8). Statistical analysis shows that $8.7 \%$ of the Penrith Sandstone and $7.3 \%$ of the St Bees Sandstone have not been affected by peak nitrate. 


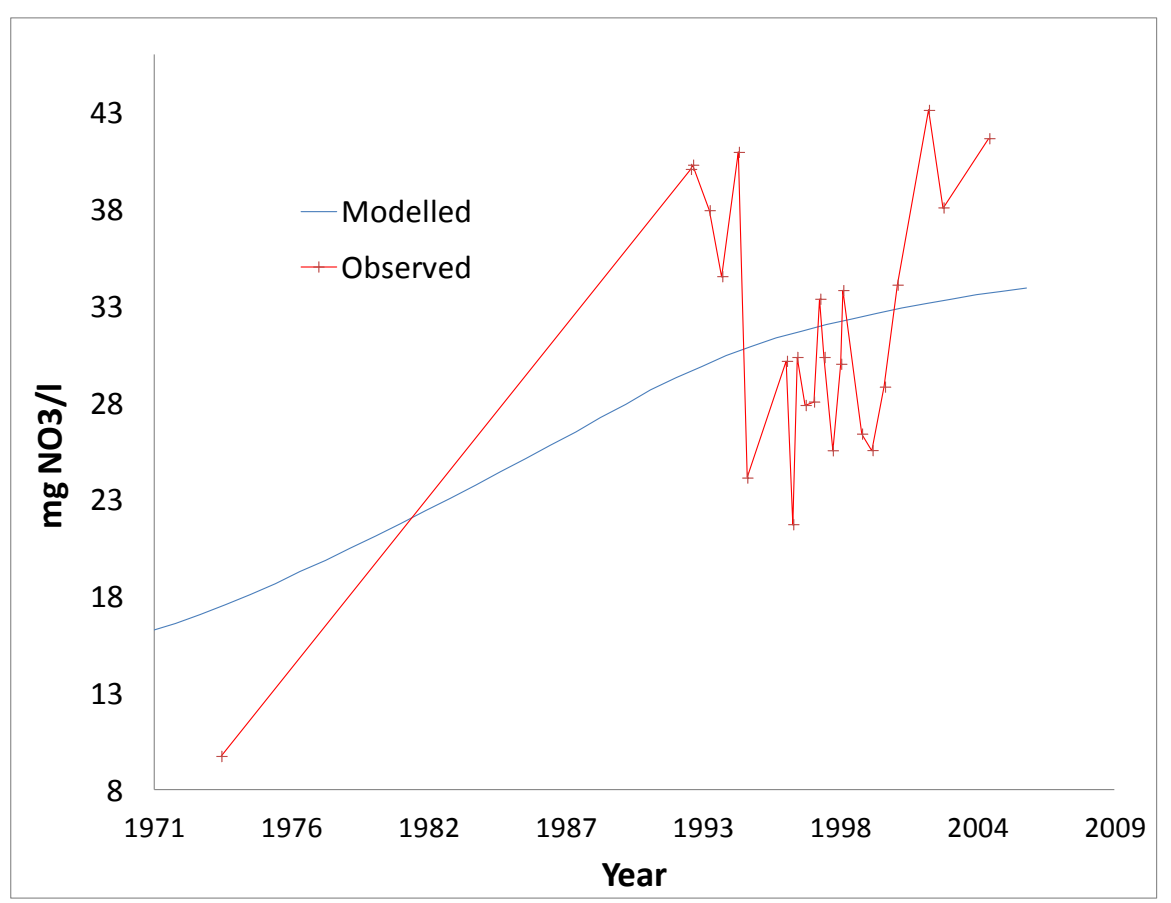

Fig. 6 The modelled and observed yearly nitrate concentration in the Bowscar borehole.

The distributed maps for nitrate concentration at the water table for each year between 1925 and 2040 were produced. The results show that the average nitrate concentration at the water table across the study area has reached its peak and will decrease over the next 30 years (Fig. 9). Some of unaffected areas with thicker USZs around Beacon Edge, Fairhills, Bowscar, Nord Vue, Low Plains, Gamblesby, and Bankwood Springs, will be affected by peak nitrate loadings between 2020 and 2030, and then retain a high nitrate concentration level (171.5 $\mathrm{mg} \mathrm{NO}_{3} \mathrm{l}^{-1}$ ) (before any groundwater dilution) around 2040. Two time series of the average nitrate concentration at the water table of the two major aquifers of the Eden Valley have been produced (Fig. 10). It suggests that the Penrith Sandstone and St Bees Sandstone have almost the same trend of average nitrate concentration change (before any groundwater dilution) at the water table. The nitrate concentrations at the water table of both aquifers reached the peak around 1995, and have declined since then. It is worth noting that the unrealistic high nitrate concentration in Fig. 9 is not the bulk groundwater nitrate concentration but the one at the water table (For modelling purposes it was assumed that nitrate stays at a very thin layer at the water table before the dilution process). However, the nitrate concentration at the water table is a good indicator of the trend of nitrate present in the groundwater regime.

\section{Discussion}

A significant and spatially variable thickness of the USZs, which determines the nitrate lag time in the USZs, is one of the major controls on nitrate groundwater concentrations in the area. This lag time between surface nitrate loading and entry to groundwater is rarely taken into account in current environmental management strategies, but it is critical to effective management and control of nutrient pollution. The method developed in this study can answer the question of when the nitrate in the groundwater at any a time point was loaded into the unsaturated zones, such as Fig. 7; the modelled results can also provide the information on the time when the historic peak nitrate loading has reached (or will reach) the water table in the area (e.g. Fig. 8); according to groundwater quality observations, whilst most have low nitrate concentrations, there are a significant number of boreholes where nitrate concentrations are above $50 \mathrm{mg} \mathrm{NO}_{3} \mathrm{l}^{-1}$ but there does not appear to be a systematic distribution of these higher nitrate groundwater bodies (Butcher et al., 2003). Most parts of the study area have been affected by the peak nitrate loading (around 1983), and the nitrate 
entering the groundwater system is now declining. This explains the low nitrate concentration in the most of the study area; but for those SPZs with variable thicker USZs, some of them are being affected or will be affected by the peak nitrate loading showing locally high or increasing nitrate groundwater concentrations. This explains why some boreholes have high and (or) increasing nitrate concentrations. These results are significant in supporting decision making for achieving environmental objectives in much shorter timescales. For example, the decreasing trend of the average groundwater nitrate concentration is good news, however, special attention should be paid to the areas where the historic peak nitrate loading has not yet arrived; the better appreciation of the nitrate lag time in the USZs in the study area could mean that inappropriate controls are avoided as a result of removing conflicts between decision makers, environmentalists and industry. Moreover, the results of studies like this should also help decision makers to define a sensible timescale to witness the effect of an action. 


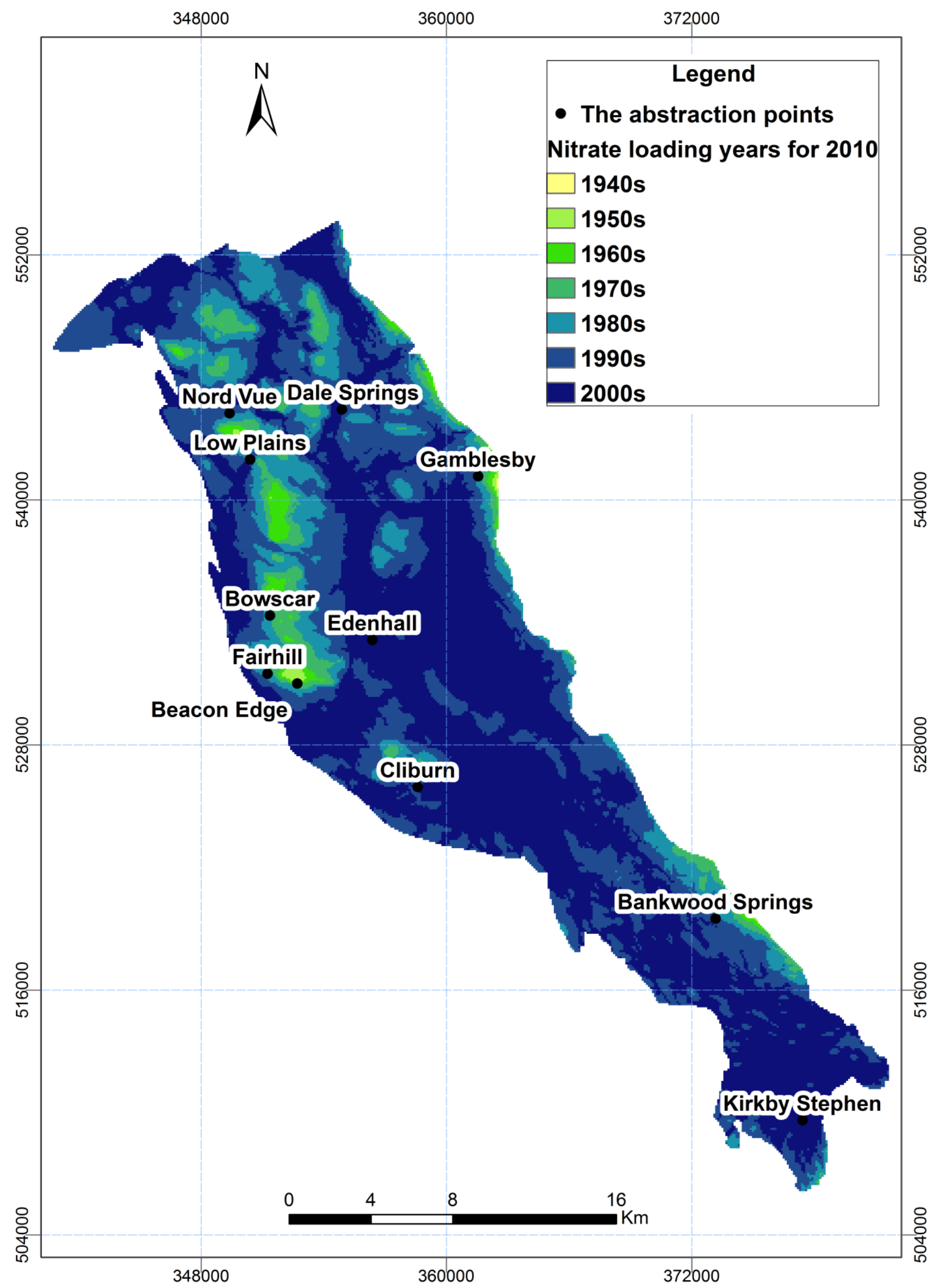

Fig. 7 The loading time for nitrate arriving at the water table of the Eden Valley in 2010. 


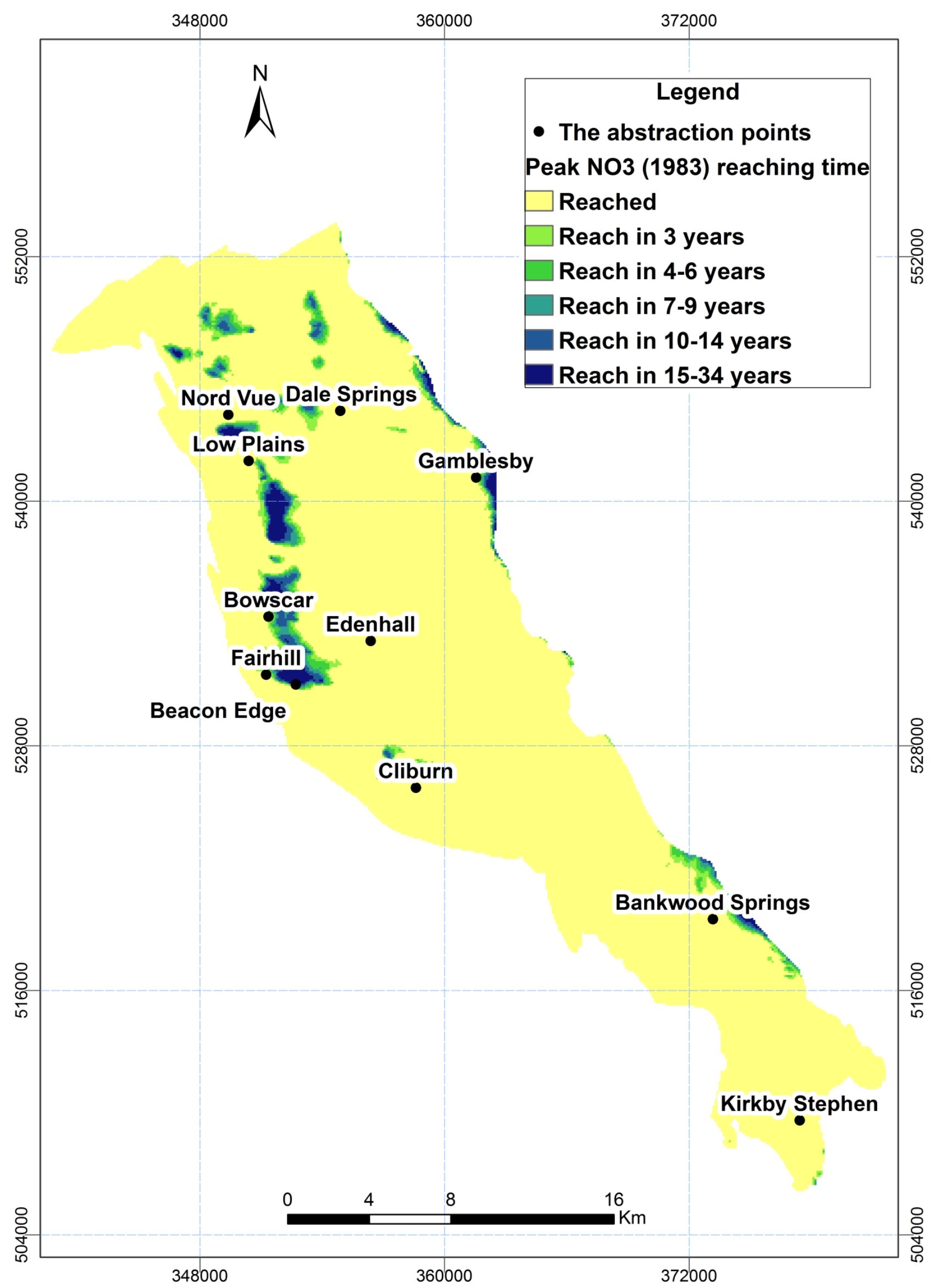

Fig. 8 The future arrival time for the peak nitrate loading (around 1983) from 2010 


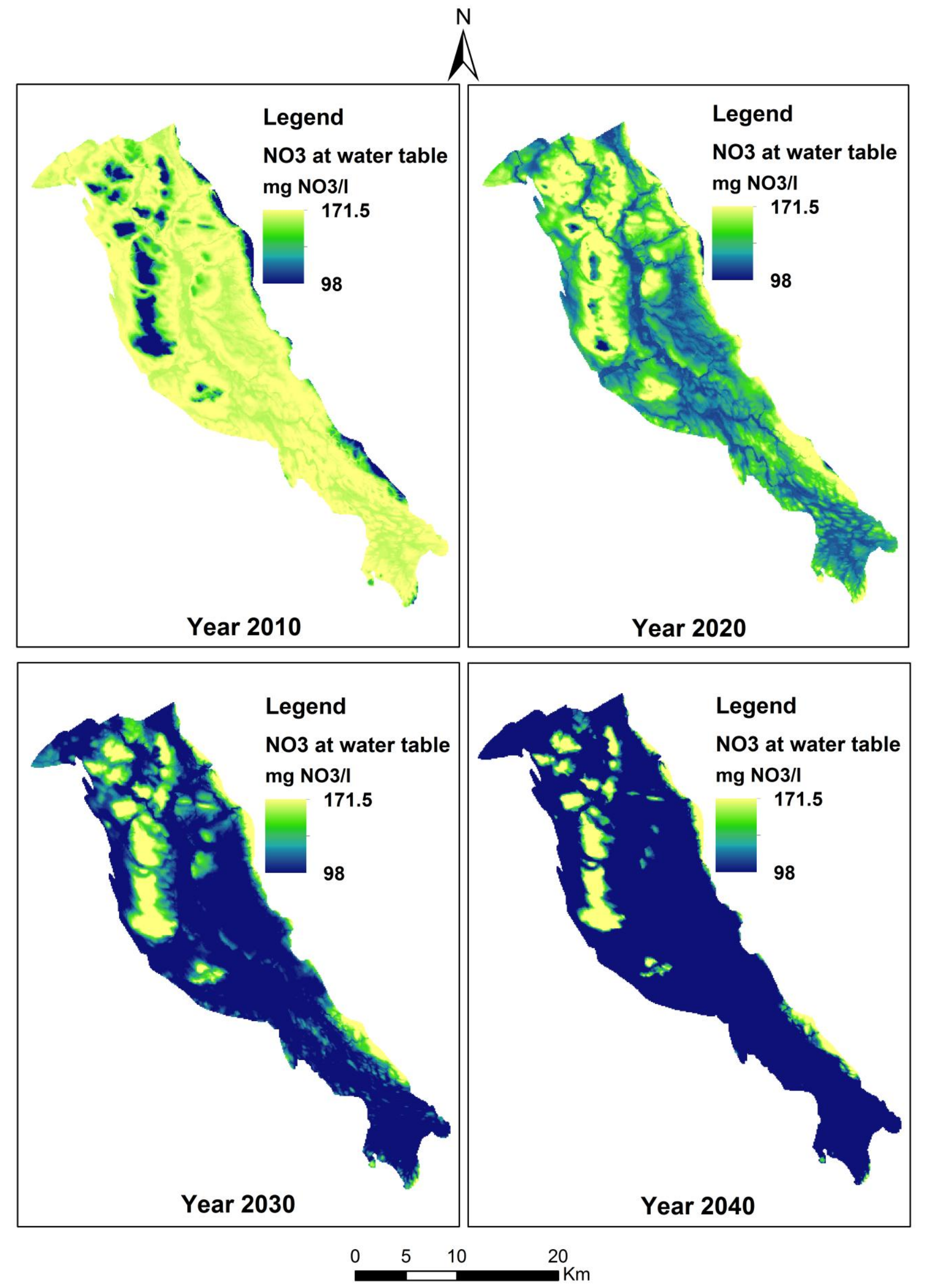

Fig. 9 The modelled nitrate concentrations at water table in the next 30 years 


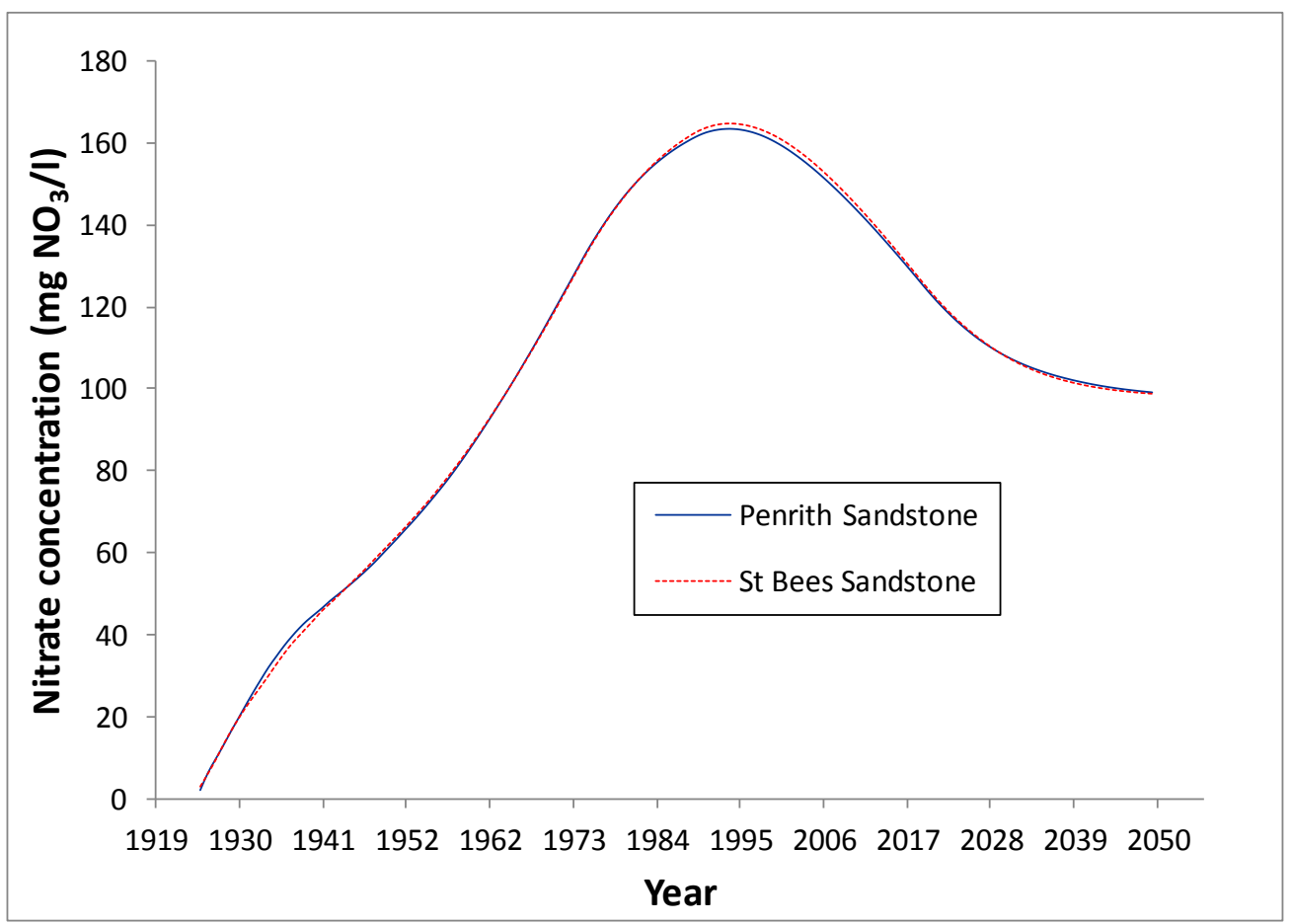

Fig. 10 The time series of the average nitrate concentration at the water table (before groundwater dilution) of two major aquifers in the Eden Valley

As mentioned above, groundwater and river water may heavily influence each other's qualities through the groundwater-surface water interactions. Therefore, it is necessary to study the impact of nitrate lag time in the USZs on both groundwater and surface water in an integrated way in the future study.

The method and models developed in this study are readily-transferable to other regions for any diffuse conservative pollutant. In other numerical modelling work that is relevant to our study, most of numeric models have a very large number of parameters (e.g. Almasri and Kaluarachchi, 2007; Krause et al., 2008; Ledoux et al., 2007), but the models adopted in this study have a limited number of parameters that are generally readily available, thus making their applications easier.

It was assumed in this study that the source of nitrate is from agricultural diffuse source and the land-use in the area were simplified as one single average type hence a single nitrate input function. Butcher et al., (2003) argued that localised nitrate point sources near to small volume abstractions might be another reason for the unevenly distributed groundwater nitrate concentrations. In addition, a constant groundwater recharge value was used in this study. Therefore, it would be useful to consider detailed land-use types, the nitrate point sources and detailed distributed groundwater recharge in the future study.

\section{Conclusions}

The nitrate transport process and its lag time in the thick Permo-Triassic sandstone USZs and saturated zones at a catchment scale can be simulated through an integrated modelling method that involves the nitrate time bomb, GISGroundwater, and N-FM numerical models. This method is readily-transferable to other areas for any diffuse conservative pollutant.

The study area has a variable thickness of the USZ $(0-183 \mathrm{~m})$ hence a large range of nitrate transport time (lag time) in the USZ (up to about 60 years). Groundwater nitrate in most of the area was from the 1980s - 2000s, whilst the groundwater nitrate in some of SPZs was loaded into the system during the 1940s - 1970s; the peak nitrate loading around 1983 has affected most of the 
study area, and will arrive at the water table in some of SPZs within the next 34 years. Large and spatially variable thickness of the USZ is one of the major reasons for unevenly distributed groundwater nitrate concentrations in the study area. The average nitrate concentration in the whole area, which reached the peak value around 1995, has a declining trend, but the areas with thicker USZs, which have not been affected by the peak nitrate loading, will be subject to a localised high or increasing groundwater nitrate concentrations in the next few decades. These findings are significant in supporting decision making for achieving environmental objectives in shorter timescales and in defining a reasonable timescale before seeing groundwater quality improvements resulting from management actions.

\section{Acknowledgements}

We are grateful to CEH and the Environment Agency of England \& Wales for providing datasets for this study. Ann T. Williams is acknowledged for her help in reviewing this paper.

\section{Conflict of interest}

The authors declare that they have no conflict of interest. The guest editors/authors declare that they have no conflict of interest with the conference sponsors.

\section{References}

Addiscott, T.M., 2005. Nitrate, Agriculture and the Environment. CAB International: Wallingford; 279.

Addiscott, T.M., Whitmore, A.P., Powlson, D.S., 1991. Farming, Fertilizers and the Nitrate Problem. CAB International: Wallingford; 170.

Allen, D.J., Brewerton, L.J., Coleby, L.M., Gibbs, B.R., Lewis, M.A., MacDonald, A.M., Wagstaff, S.J., Williams, A.T., 1997. The physical properties of major aquifers in England and Wales. British Geological Survey Technical Report WD/97/34; Environment Agency R\&D Publication 8, British Geological Survey, Keyworth, Nottingham.

Almasri, M.N., Kaluarachchi, J.J., 2007. Modeling nitrate contamination of groundwater in agricultural watersheds. Journal of Hydrology 343, 211-229.

Arthurton, R.S., Burgess, I.C., Holliday, D.W., 1978. Permian and Triassic in: The Geology of the Lake District edited by F Moseley. Yorks Geological Society Occasional Publication No 3.

Arthurton, R.S., Wadge, A.J., 1981. Geology of the Country around Penrith. Memoir for 1:50 000 geological sheet 24. British Geological Survey, NERC. HMSO.

Brouyère, S.B., Dassargues, A., Hallet, V., 2004. Migration of contaminants through the unsaturated zone overlying the Hesbaye chalky aquifer in Belgium: a field investigation. Journal of Contaminant Hydrology 72: 135-164.

Bryan, N.S., 2006. Nitrite in nitric oxide biology: Cause or consequence? A systems-based review. Free Radical Biology \& Medicine 41: 691-701. DOI:10D1016/j.freeradbiomed.2006D05D019.

Burt, T.P., Howden, N.J., Worrall, F., Whelan, M.J., Bieroza, M., 2011. Nitrate in United Kingdom Rivers: Policy and Its Outcomes Since 1970. Environ. Sci. Technol. 45, 175-181.

Butcher, A.S., Lawrence, A.R., Jackson,C., Cunningham, J., Cullis,E., Hasan, K., Ingram, J., 2003. Investigation of rising nitrate concentrations in groundwater in the Eden valley, Cumbria: Scoping study. Environment Agency R\&D Report $\mathrm{NC} / 00 / 24 / 14$.

Butcher, A.S., Lawrence, A.R., Tribe, E., Hannay, S., Hasan, K., Merrin, P., 2005. Investigation of rising nitrate concentrations in groundwater in the Eden valley, Cumbria. Summary Report 1: Catchment Water Quality Survey. BGS Commissioned Report CR/05/258N.

Butcher, A., Lawrence, A., Mansour, M., Burke, S., Ingram, J., Merrin, P., 2008. Investigation of rising nitrate concentrations in groundwater in the Eden Valley, Cumbria. 2, unsaturated zone studies. British Geological Survey, 37pp. BGS Commissioned Report OR/08/023.

Campbell, J.D., Kotloff, K.L., et al, 2004 Invasive pneumococcal infections among hospitalised children in Bamko, Mali. Pediatric Disease Journal 23, 642-649.

Daily, P., Ingram, J., Johnson, R., 2006. Groundwater Quality Review: The Permo-Triassic Sandstone Aquifers of the Eden Valley and Carlisle Basin Groundwater Quality Monitoring Unit. Environment Agency Report, 6438A R1.

DEFRA, 2002. Agriculture and Water: A Diffuse Pollution Review. Department for Environment, Food and Rural Affairs, London, UK.

DEFRA, 2006a. Post-conciliation partial regulatory impact assessment. Groundwater proposals under Article 17 of the Water Framework Directive. Draft Final Report. DEFRA, London.

DEFRA, 2006b. Nitrates in water-the current status in England (2006). ADAS report to Defra-supporting paper D1 for the consultation on implementation of the Nitrates Directive in England.

ESI, 2004. Groundwater Levels in the North West Region. ESI report 6189A.

European Environment Agency, 2000. Groundwater quality and quantity in Europe. Environmental Assessment Report, 3.

Foster, S.S.D., 1993. The Chalk aquifer- its vulnerability to pollution. In The Hydrogeology of the Chalk of North-West Europe, Downing RA, Price M, Jones GP (eds). Clarendon Press: Oxford; 1-13.

Foster, S.S.D., 2000. Assessing and controlling the impacts of agriculture on groundwater - from barley barons to beef bans. Quarterly Journal of Engineering Geology and Hydrogeology 33: 263-280. 
Foster, S.S.D., Crease R.I., 1974. Nitrate pollution of Chalk groundwater in East Yorkshire - a hydrogeological appraisal. Journal of the Institute of Water Engineer 28: 178-194.

Foster S.S.D., Cripps, A.C., Smith-Carington, A.K., 1982. Nitrate leaching to groundwater. Philosophical Transactions of the Royal Society of London B 296: 477-489.

Geake, A.K., Foster, S.S.D., 1989. Sequential isotope and solute profiling in the unsaturated zone of British Chalk. Hydrological Sciences Journal 34: 79-95.

Hoffmann, M., Johnsson, H., Gustafson, A., Grimvall, A., 2000. Leaching of nitrogen in Swedish agriculture-a historical perspective. Agriculture,Ecosystems and Environment 80: 277-290.

Howden, N. J. K., Burt, T. P., Worrall, F., Mathias, S., Whelan, M.J., 2011. Nitrate pollution in intensively farmed regions: What are the prospects for sustaining high-quality groundwater?, Water Resour. Res. 47, W00L02.

Jackson, B.M., Wheater, H.S., Wade, A.J., Butterfield, D., Mathias, S.A., Ireson, A.M., Butler, A.P., Mclntyre, N.R., Whitehead, P.G., 2007. Catchment-scale modelling of flow and nutrient transport in the Chalk unsaturated zone. Ecological Modelling 209, 41-52.

Kahrl, F., Yunju, L., Roland-Holst, D., Jianchu, X., Zilberman, D., 2010. Toward sustainable use of nitrogen fertilizers in china. ARE Update 14(2), 5-7. University of California Giannini Foundation of Agricultural Economics.

Kinniburgh, D.G., Gale, I.N., Gooddy, D.C., Darling, W.G., Marks, R.J., Gibbs, B.R., Coleby, L.M., Bird, M.J., West, J.M., 1994. Denitrification in the unsaturated zones of the British Chalk and Sherwood Sandstone aquifers. British Geological Survey Technical Report WD/99/2.

Krause, S., Jacobs, J., Voss, A., Bronstert, A., Zehe, E., 2008. Assessing the impact of changes in landuse and management practices on the diffuse pollution and retention of nitrate in a riparian floodplain. Science of the Total Environment 389, 149-164.

Lake, I.R., Lovett, A.A., Hiscock, K.M., Betson, M., Foley, A., Sünnenberg, G., Evers, S., Fletcher, S., 2003. Evaluating factors influencing groundwater vulnerability to nitrate pollution: developing the potential of GIS. Journal of Environmental Management 68: 315-328.

Lawrence, A.R., Foster, S.S.D., 1986. Denitrification in a limestone aquifer in relation to the security of low-nitrate groundwater supplies. Journal of the Institute of Water Engineering Sciences 40: 159-172.

Ledoux, E., Gomez, E., Monget, J.M., Viavattene, C., Viennot, P., Ducharne, A., Benoit, M., Mignolet, C., Schott, C., Mary, B., 2007. Agriculture and groundwater nitrate contamination in the Seine basin. The STICS-MODCOU modelling chain. Science of the Total Environment 375: 33-47.

Lord, E.I., Johnson, P.A., Archer, J.R., 1999. Nitrate Sensitive Areas: a study of large scale control of nitrate loss in England. Soil Use and Management 15: 201-207.

Millward D and McCormac M. 2003. Geology of the Appleby district. An explanation of the geological map Sheet 30 Appleby. British Geological Survey.

Oakes, D.B., Young, C.P., Foster, S.S.D., 1981. The effects of farming practices on groundwater quality in the United Kingdom. Science of the Total Environment 21: 17-30.

Palmer, R.C., 1987. Groundwater Vulnerability (7 maps and booklets covering Severn-Trent Water Authority area), Soil Survey and Land Research Centre: Cranfield.

Patrick, C.K., 1978. Hydrogeology. In: Moseley, F., (Ed.), The Geology of the Lake District. Yorkshire Geological Society (Occasional Publication No. 3).

Pretty, J.N., Brett, C., Gee, D., Hine, R.E., Mason, C.F., Morison, J.I.L., Raven, H., Rayment, M.D., Van der Bijl, G., 2000. An assessment of the total external costs of UK agriculture. Agricultural Systems 65(2): 113-136.

Rivett, M.O., Smith, J.N.W., Buss, S.R., Morgan, P., 2007. Nitrate occurrence and attenuation in the major aquifers of England and Wales. Quarterly Journal of Engineering Geology and Hydrogeology 40: 335-352.

Spears, D.A., 1979. Porewater composition in the unsaturated zone of the Chalk, with particular reference to nitrates. Quarterly Journal of Engineering Geology and Hydrogeology 12: 97-105.

Stuart, M.E., Chilton, P.J., Kinniburgh, D.G., Cooper, D.M., 2007. Screening for long-term trends in groundwater nitrate monitoring data. Quarterly Journal of Engineering Geology and Hydrogeology 40: 361-376.

Wang, L., Mansour, M., Hughes A., 2010. Description of the GIS based regional groundwater flow model. Internal Report IR/10/070, British Geological Survey, Keyworth, Nottingham, UK.

Wang, L., Stuart, M.E., Bloomfield, J.P., Butcher, A.S., Gooddy D.C., McKenzie, A.A., Lewis, M.A.,Williams, A.T., 2012. Prediction of the arrival of peak nitrate concentrations at the water table at the regional scale in Great Britain. Hydrological Processes 26, 226-239.

Wang, L., Yang, Y.S., 2008. An approach to catchment-scale groundwater nitrate risk assessment from diffuse agricultural sources: a case study in the Upper Bann, Northern Ireland, Hydrological Processes, 22 (21), 4274-4286.

Yang, Y.S., Wang, L., 2010 Catchment-scale vulnerability assessment of groundwater pollution from diffuse sources using the DRASTIC method: a case study. Hydrological Sciences Journal, 55 (7). 1206-1216. 10.1080/02626667.2010.508872.

Yang, C.Y., Wu, D.C., Chang, C.C., 2007. Nitrate in drinking water and risk of death from colon cancer in Taiwan. Environment International 33 (5), 649-653.

Young, C.P., Oakes, D.B., Wilkinson, W.B., 1976. Prediction of future nitrate concentrations in groundwater. Ground Water 14: 426-438. 